\title{
Study of Determinants of e-CRM in Influencing Consumer Satisfaction in B2C Websites
}

\author{
Rui Liu, Weijun Wang \\ Department of Information Management, HuaZhong Normal University, \\ Wuhan 430079 , China \\ liuruiccnu@hotmail.com, wangwj@mail.ccnu.edu.cn
}

\begin{abstract}
This study empirically develops a model indicating the determinants of e-CRM as well as explaining the relationship between eCRM and customer satisfaction in $\mathrm{B} 2 \mathrm{C}$ websites. Based on the $7 \mathrm{C}$ model demonstrated by Rayport,J.F.\&Jaworski,B.J and the Conceptual Model of Service Quality researched by Parasuraman, a theoretical framework that consists of e-CRM initiatives: context, content, customization, communication, membership, commerce, safety, customer satisfaction is further expanded. And then, this study puts forwards some suggestions to both researchers and practitioners: the function of e-CRM and the importance of customer satisfaction should be well learned; the functions of content, customization and commerce of $\mathrm{B} 2 \mathrm{C}$ websites should be enhanced and the factors of context, membership and communication should be added when carrying out e-CRM strategy.
\end{abstract}

\section{Introduction}

At present, the researches on e-CRM and customers' satisfaction in China are always papers which demonstrate the two subjects respectively. Among few empirical researches in this field, a study on the relationship between service quality and customer satisfaction for general portals sorts out 4 influential factors named "ease of use" "empathy", "information quality" and "techniques of website "for general portals[1]. Besides, experts from Taiwan study on-line customer satisfaction from service quality, product quality and system quality [2] [3].

The book CRM theory design practice [4] and Customer Relationship Management [5] introduce the concept and function of e-CRM which contributes to this research.

Determinants of e-CRM in Influencing Customer Satisfaction written by Yan Liu, Chang Feng Zhou, and Ying-Wu Chen studies the relationship between eCRM and customers' satisfaction from three factors(system quality, information quality, service quality) and two intrinsic success(responsiveness, efficiency)[6].

Zhang Cuiling [7] quotes 7C model (context/content/community/customizetion/communication/connection/ commerce) constructed by Rayport, J.F. \& Jaworski, and it introduces seven factors of CRM applied to websites for Electronic Commerce.

Previous researches can be summed as follows: 
(1) The theory of e-CRM has been introduces by more and more scholars and experts, some business organizations has put that into practice.

(2) CRM, service quality and customer satisfaction has been applied to online service of Electronic Commerce and some models have been developed for evaluating on-line service.

(3) Few researches have been done for studying the relationship between e$\mathrm{CRM}$ and customer satisfaction.

\section{Method}

In 7C model demonstrated by Rayport, J.F. \&Jaworski, B.J, community also refers that website offers BBS and allows leaving messages on-line. In fact, the two functions can be put into content as a way of representing information; thus, some other strategies of membership are added to connection and a new factor called membership is formed; besides, based on the paper Empirical Study of Influential Elements of E-satisfaction [8], the factor safety is added to our model. According to Expectation Conformation/Disconfirmation mode [9] and the Conceptual Model of Service Quality [10], a theoretical framework that consists of e-CRM initiatives: context, content, customization, membership, communication, commerce, safety, customer satisfaction is further expanded. (see Fig. 1)

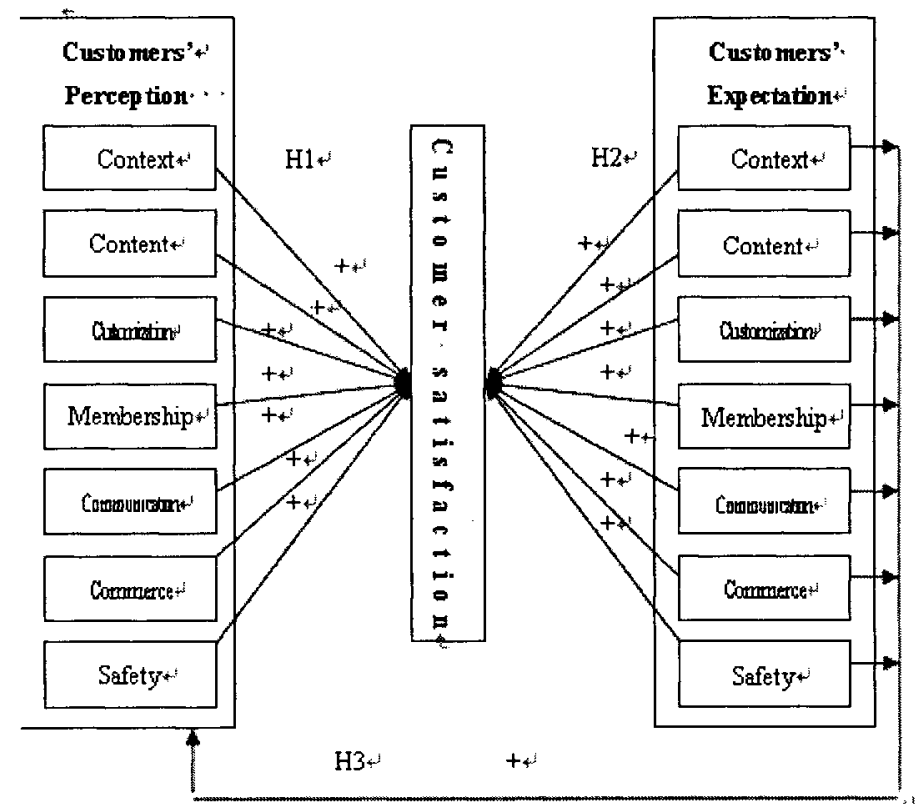

Fig. 1.The theoretical framework

This leads to the following hypotheses: 
$\mathrm{H} 1$ : customers' perception of $\mathrm{B} 2 \mathrm{C}$ website's performances has a remarkable and positive correlation with consumer satisfaction.

$\mathrm{H} 2$ : customers' expectation of $\mathrm{B} 2 \mathrm{C}$ website's performances has a remarkable and positive correlation with consumer satisfaction.

H3: customers' expectation has a remarkable and positive correlation with customers' perception.

This model was tested by means of the statistical analysis method of SPSS.A total of 51 questionnaire items were established to measure the extent to which participants gave to the perception, expectation and customer satisfaction towards e-CRM provided in $\mathrm{B} 2 \mathrm{C}$ websites. A five point Likert scale, ranging from $1=$ strongly disagree to $5=$ strongly agree, was employed.

Methods used in this research include:

(1) Information investigation, acquisition work.

(2) Comparison, analysis, deduction.

(3) Survey study. Designing and using a questionnaire.

(4) Factor analysis and regression analysis. Using SPSS to test sample data.

\section{Analysis}

The results of Bartlett test of sphericity and Kaiser-Meyer-Olkin measure of sample adequacy are shown in Table 1:

Table 1. KMO and Bartlett's Test

\begin{tabular}{|c|l|r|}
\hline \multicolumn{2}{|c|}{ Kaiser-Meyer-Olkin Measure of Sampling Adequacy. } & 0.858 \\
\hline \multirow{2}{*}{$\begin{array}{c}\text { Bartlett's Test of } \\
\text { Sphericity }\end{array}$} & Approx. Chi-Square & 2871.727 \\
\cline { 2 - 3 } & df & 276 \\
\cline { 2 - 3 } & Sig. & 0.000 \\
\hline
\end{tabular}

Then, Reliability Coefficients is used to test customers' perception and customer satisfaction. (See Table 2)

Table 2. Reliability Analysis-Scale (Alpha)

\begin{tabular}{|c|l|c|c|}
\hline & \multicolumn{1}{|c|}{ Factor } & Item & Cronbach $\alpha$ \\
\hline \multirow{5}{*}{ Customers 'perception } & Context & II- I3 & 0.8749 \\
\cline { 2 - 4 } & Content & I4-I8 & 0.8170 \\
\cline { 2 - 4 } & Customization & $\begin{array}{c}\text { I9 I10、 } \\
\text { I17 I18 }\end{array}$ & 0.8281 \\
\cline { 2 - 4 } & Membership & I11-I13 & 0.8292 \\
\cline { 2 - 4 } & Communication & I14-I16 & 0.8176 \\
\cline { 2 - 4 } & Commerce & I19-I21 & 0.8510 \\
\cline { 2 - 4 } & Safety & I22-I24 & 0.8612 \\
\hline \multirow{2}{*}{ Customer satisfaction } & $\begin{array}{l}\text { Customer } \\
\text { Satisfaction }\end{array}$ & I49-I51 & 0.6815 \\
\hline
\end{tabular}

According to the analysis above, the entire 204 valid sample are quite fit for further analysis. 
This study empirically develops a model indicating 7 determinants of e-CRM as well as discussing how customers' perception affects customer satisfaction, how customers' expectation affects customer satisfaction and how perception affects expectation. In order to avoid Collinarity in Regression Analysis, Pearson Correlation was applied. And the largest numerical value $(0.562<0.75)$ indicated that it was fit for the Regression Analysis.

\subsection{How customers' perception affects customer satisfaction}

According to Parasuraman, customers' perception of service quality affects positively customer satisfaction [11]; Yi studies determinants of customer satisfaction in diverse products. It reveals that customers' perception affects positively customer satisfaction in the category of low ambiguity products [12].Former studies can lead to the following hypotheses:

HI-l: Context which customer perceived affects positively customer satisfaction.

HI-2: Content which customer perceived affects positively customer satisfaction.

H1-3: Customization which customer perceived affects positively customer satisfaction.

HI-4: Membership which customer perceived affects positively customer satisfaction.

H1-5: Communication which customer perceived affects positively customer satisfaction.

HI-6: Commerce which customer perceived affects positively customer satisfaction.

H1-7: Safety which customer perceived affects positively customer satisfaction.

Table 3 and Table 4 illustrate the coefficients of customers' perception and customer satisfaction.

Table 3. Model Summary

\begin{tabular}{|c|c|c|c|}
\hline $\mathbf{R}$ & R Square & $\begin{array}{c}\text { Adjusted R } \\
\text { Square }\end{array}$ & $\begin{array}{c}\text { Std. Error of } \\
\text { the Estimate }\end{array}$ \\
\hline $.514(\mathrm{a})$ & .264 & .238 & .56770 \\
\hline
\end{tabular}


Table 4. Coefficients (Dependent Variable: customer satisfaction)

\begin{tabular}{|c|c|c|c|c|}
\hline & Beta & $t$ & Sig. & R Square \\
\hline (Constant) & & 8.905 & .000 & \multirow{8}{*}{.264} \\
\hline context & .033 & .431 & .667 & \\
\hline content & .303 & 3.472 & .001 & \\
\hline customization & .402 & 5.180 & .000 & \\
\hline membership & .015 & .183 & .855 & \\
\hline communication & .077 & 1.029 & .305 & \\
\hline commerce & .160 & 2.100 & .037 & \\
\hline safety & .106 & 1.307 & .193 & \\
\hline
\end{tabular}

Table 5 shows that H1-2, H1-3 and H1-6 are supported after hypotheses testing.

Table 5. Results 1

\begin{tabular}{|l|l|l|l|l|l|l|l|}
\hline Hypotheses & H1-1 & H1-2 & H1-3 & H1-4 & H1-5 & H1-6 & H1-7 \\
\hline Results & No & Supportive & Supportive & No & No & Supportive & No \\
\hline
\end{tabular}

\subsection{How customers' expectation affects customer satisfaction}

According to Yi's study, customers' expectation affects positively customer satisfaction in the category of high ambiguity products [12]; Churchill and Surprenant find out that customers' expectation affects positively customer satisfaction in nondurable assets [13]; when exploring the impact of online service quality on portal site Usage, Lin and $\mathrm{Wu}$ also demonstrate that customers' expectation affects customer satisfaction positively [14]. Given the researches above, we can come up to the following hypotheses:

H2-1: Context which customer expected affects positively customer satisfaction.

H2-2: Content which customer expected affects positively customer satisfaction.

H2-3: Customization which customer expected affects positively customer satisfaction.

H2-4: Membership which customer expected affects positively customer satisfaction.

H2-5: Communication which customer expected affects positively customer satisfaction.

H2-6: Commerce which customer expected affects positively customer satisfaction.

H2-7: Safety which customer expected affects positively customer satisfaction.

Table 6 and Table 7 illustrate the coefficients of customers' expectation and customer satisfaction. 
448 Study of Determinants of e-CRM in Influencing Consumer Satisfaction in B2C

Websites

Table 6. Coefficients (Dependent Variable: customer satisfaction)

\begin{tabular}{|c|c|c|c|c|}
\hline & Beta & $\mathbf{t}$ & Sig. & R Square \\
\hline (Constant) & & 6.655 & .000 & \multirow{8}{*}{.129} \\
\hline context & .014 & .146 & .884 & \\
\hline content & .100 & .800 & .425 & \\
\hline customization & .050 & .485 & .628 & \\
\hline membership & -.059 & -.571 & .569 & \\
\hline $\begin{array}{l}\text { communicati } \\
\text { on }\end{array}$ & -.050 & -.432 & .666 & \\
\hline commerce & .249 & 1.967 & .051 & \\
\hline safety & .077 & .566 & .572 & \\
\hline
\end{tabular}

Table 7. Model Summary

\begin{tabular}{|c|r|r|r|}
\hline R & R Square & \multicolumn{1}{c|}{$\begin{array}{c}\text { Adjusted R } \\
\text { Square }\end{array}$} & $\begin{array}{c}\text { Std. Error of the } \\
\text { Estimate }\end{array}$ \\
\hline $.360(a)$ & .129 & .098 & .61746 \\
\hline
\end{tabular}

The results of hypotheses testing are shown in Table 8:

Table 8. Results 2

\begin{tabular}{|l|l|l|l|l|l|l|l|}
\hline Hypotheses & H2-1 & H2-2 & H2-3 & H2-4 & H2-5 & H2-6 & H2-7 \\
\hline Results & No & No & No & No & No & No & No \\
\hline
\end{tabular}

\subsection{How customers' expectation affects customers' perception}

Spreng and Mackoy reveal that customers' expectation affects customers' perception positively [15]; Song also demonstrates that when studying the relationship between service quality and customer satisfaction for general portals [1]. These can lead to the following hypotheses:

H3-l: Context which customer expected affects positively that customer perceived.

H3-2: Content which customer expected affects positively that customer perceived.

H3-3: Customization which customer expected affects positively that customer perceived.

H3-4: Membership which customer expected affects positively that customer perceived.

H3-5: Communication which customer expected affects positively that customer perceived.

H3-6: Commerce which customer expected affects positively that customer perceived.

H3-7: Safety which customer expected affects positively that customer perceived. 
Table 9 and Table 10 illustrate the coefficients of customers' expectation and customers' perception.

Table 9. Model Summary

\begin{tabular}{|c|r|r|r|}
\hline R & R Square & $\begin{array}{c}\text { Adjusted R } \\
\text { Square }\end{array}$ & $\begin{array}{c}\text { Std. Error of } \\
\text { the Estimate }\end{array}$ \\
\hline $.452(a)$ & .204 & .176 & .51464 \\
\hline
\end{tabular}

Table 10. Coefficients (Dependent Variable: customers' perception)

\begin{tabular}{|c|c|c|c|c|}
\hline & Beta & $t$ & Sig. & R Square \\
\hline (Constant) & & 6.775 & .000 & \multirow{8}{*}{.204} \\
\hline context & .239 & 2.662 & .008 & \\
\hline content & .280 & 2.336 & .021 & \\
\hline customization & .010 & .098 & .922 & \\
\hline membership & .046 & -.469 & .640 & \\
\hline communication & .134 & 1.206 & .229 & \\
\hline commerce & $\begin{array}{r}- \\
.020\end{array}$ & -.164 & .870 & \\
\hline safety & 100 & -.776 & .439 & \\
\hline
\end{tabular}

As a result, $\mathrm{H}$ 3-1 and $\mathrm{H}$ 3-2 are supported. (see Table 11)

Table 11. Results 3

\begin{tabular}{|l|l|l|l|l|l|l|l|}
\hline Hypotheses & H3-1 & H3-2 & H3-3 & H3-4 & H3-5 & H3-6 & H3-7 \\
\hline Results & Supportive & Supportive & No & No & No & No & No \\
\hline
\end{tabular}

\section{Discussion}

We'll discuss the results of Data Analysis from 3 aspects:

(1)Among the 7 factors we test in the model, "Customization" gets the highest Beta quotiety 0.402 ; the Beta quotiety of "Content" is 0.303 and "Commerce" gets the result of 0.160 which ranked 3rd.As a result, operators of EC websites should improve service quality according to the importance of the three factors.

(2)About how customers' perception affects customer satisfaction, we find out that customers' perception affects positively customer satisfaction in "content", "customization" and "commerce". "Context" which customer perceived does not influence customer satisfaction obviously. However, "membership" and "communication" which are thought to be important to customer satisfaction don't have effects on customer satisfaction. This can be 
explained by the Model of KANO [16]. "Membership" and "safety" can be put into the category of "Surprise \& Delight" factors. These may seem to be less important but can really make the products stand out from the others.

(3)About how customers' expectation affects customer satisfaction, none of the 7 factors has impact on customer satisfaction. Reasons can be that people all give high scores to each item of the questionnaire. As a result, no matter how customers' perception changes, the expectations always remain to a higher level.

(4)About how customers' expectation affects customers' perception, "context" and "content" which customer expected affect positively on that customer perceived.

\section{Conclusion}

The results show that: customers' perception of $\mathrm{B} 2 \mathrm{C}$ website's performances has a remarkable and positive correlation with consumer satisfaction from the aspects of content, customization and commerce; customers' expectation has as remarkable and positive correlation with customers' perception from the aspects of context and content; the results also indicates that the factor of customers' age has remarkable influence on website's performances which consumers perceived when shopping online.

Some suggestions can be put forward to both researchers and practitioners: the function of e-CRM and the importance of customer satisfaction should be well learned; the functions of content, customization and commerce of $\mathrm{B} 2 \mathrm{C}$ websites should be enhanced; to be specific, B2C websites should take the following measures:

(1)Offering searching engine and BBS for consumers to retrieve information and communicate when shopping on-line;

(2) Updating the content of $\mathrm{B} 2 \mathrm{C}$ website timely;

(3)Sending Greeting Cards or small gifts to regular customers;

(4)Offering customized goods;

(5)Offering diverse channels for ordering, payment and delivery; allowing consumers to choose the way they like;

Functions of content, customization and commerce of websites under B2C pattern should be enhanced; the factors of context, membership and communication should be added when carrying out e-CRM strategy.

\section{Acknowledgments}

This reasearch is supported by Program for New Century Excellent Talents in University (NCET) and National Social Science Foundation of China, Grant No. 06BTQ019.

\section{References}

1. B. C. Song, "Study on the Relationship between Service Quality and Customer Satisfaction for General Portals", Hangzhou: Zhejiang University, 25-26 (2005). 
2. Y.X. Huang, "Effects of Commodity, System and Service Quality on on-line Consumers' Loyalty-an Example of 3C Internet Shopping Store", Taiwan: Donghua University, 44-48 (2005).

3. H. R. Ye, "A Study of Customer Relationship, Service Quality and Consumers' Loyalty-an Example of Online Shopping", Taiwan, Dongwu University, 22-25(2002).

4. R. Q. He, CRM theory design practice, Electronic Industry Press, Beijing, China (2001).

5. A. Q. Zhu, Customer Relationship Management, China Finance and Economy Press, Beijing, China (2003).

6. Y. Liu, C. F. Zhou, and Y.W. Chen, "Determinants of e-CRM in Influencing Customer Satisfaction", Lecture Notes in Computer Science 4099, 767-776(2006).

7. C. L. Zhang, "Building Customer Relationship Management Oriented Websites: A Study on the Online Flowers Shop in Taiwan", Taiwan: Donghua University (2005).

8. J. X. Zha, L. S. Wang, "Empirical Study of Influential Elements of E-satisfaction", Science of Management 19(1), 52-57(2006).

9. R. L. Oliver, "A Conceptual Model of Service Quality and Service Satisfaction: Compatible Goals, Different Concepts", Advances in Service Marketing and Management 2, 65-68(1993)

10. A. Parasuraman, V.A. Zeithaml, L.L Berry, "Refinement and Reassessment to the SERVQUAL Scale", Journal of Retailing 67(4), 420(1991).

11. A. Parasuraman, V.A. Zeithaml, L.L Berry, "SERVQUAL: A Multiple-Item Scale for Measuring Customer Perceptions of Service Quality", Journal of Retailing 64, 12-40(1988).

12. Y. Yi, "The determinants of consumer satisfaction: The moderating role of ambiguity in L.McAlister and M.L.Rothschild (Eds.)", Advance in Consumer Research 20,502-506(1993).

13. G. A. Churchill and C. Surprenant, "An Investigation into to the Determinants of Customer Satisfaction", Journal of Marketing Research 19, 491-504(1982).

14. C. S. Lin and S. Wu, "Exploring the impact of online service quality on portal site Usage", Proceedings of the 35th Hawaii International Conference on System Sciences (2002).

15. R. A. Spreng and R. D. Mackoy, "An empirical examination of a model perceived service quality and satisfaction", Journal of Retailing 72(2), 201-214(1996).

16. L. Yu, Measurement of Customer Satisfaction, Social Sciences Documentation Publishing House, Beijing, China (2003).

17. A. Parasuraman, V. A. Zeithaml, L. L Berry, "Quality and Its Implications for Future Research", Journal of Marketing 49, 41-50(1985).

18. Y. Yi, "The Determinants of Consumer Satisfaction: The Moderating Role of Ambiguity in L.McAlister and M.L.Rothschild (Eds.)", Advance in consumer research 20,502-506(1993).

19. C. S. Lin, S. Wu, "Exploring the Impact of Online Service Quality on Portal Site Usage", Proceedings of the 35 th Hawaii International Conference on System Sciences (2002).

20. W.E. Sasser, R. P. Olsen, and D. D. Wyckoff, Management of Service Operation: Text and Cases, Allyn and Bacon Inc., Boston, US (1978).

21. J. E. G. Bateson, Understanding Services Consumer Behavior. In C.A. Congram, (EA.), the AMA Handbook of Marketing for the Service Industries, America Management Association, New York, US (1991).

22. J. Nunnally, Psychometric theory, McGraw-Hill Book Co, New York, US (1967).

23. J. Nunnally, Psychometric theory 2nded, McGraw-Hill Book Co., New York, US (1978). 